\title{
Studies and research on the phenomenon of hydrodynamic erosion in river beds
}

\author{
Paul-Vivian Sion ${ }^{1}$, Mihaela Avram² and Mihail Luca ${ }^{1, *}$ \\ 1 Technical University "Gheorghe Asachi" of Iasi, Romania; paul-vivian.sion@student.tuiasi.ro \\ 2 Siret Water Basin Administration, Bacau, Romania; avram_mihaela35@yahoo.com \\ 3 Technical University "Gheorghe Asachi" of Iasi, Romania; mluca2015@yahoo.com \\ *mluca2015@yahoo.com; Tel.: 0040744709809
}

Keywords: analysis models, anthropogenic factors, erosion depths, natural factors

\begin{abstract}
The phenomenon of hydrodynamic erosion affects the riverbeds in which subcrossings of pipes or bridges are located. The depth of erosion is determined at a point in the riverbed by the use of specialized computational relationships. For some works located in the riverbed it is necessary to know the erosion depths on the perimeter of the flow section. The analysis models used to investigate the phenomenon of hydrodynamic erosion were: a - topographic model; b - calculation relations from the technical regulations; $\mathrm{c}$ - erosion simulation model on a river section. The obtained results were materialized by the evolution of the erosion depths on the considered river sector over an interval of about 5-15 years. The depth of erosion on the lower course of the Moldova River showed values from $0.75 \mathrm{~m}$ to $1.65 \mathrm{~m}$ on a research sector. The research results were capitalized on the design of the rehabilitation works of the constructions present in the riverbed.
\end{abstract}

\section{Introduction}

The watercourses in Romania present in the last period of time a hydrological regime with a great variation of the maximum flows. Floods at medium and high flows over time produce important morphological changes in the minor riverbed. These changes affect the stability of the constructions located in the riverbed. The most affected works in the riverbed by the phenomenon of hydrodynamic erosion are the pipes under the crossing, the piles and abutments of the bridges, the suction of the pumping stations, the catchment windows at the water intakes, etc. Hydrodynamic erosion of water can cause partial and even total degradation of these objectives.

The morphological change of the riverbed is produced by natural and anthropogenic factors. In the last period of time, the influence of anthropogenic risk factors on the evolution of the local climate is strongly felt. Studies and research conducted at international and national level confirm this hypothesis (Luca M., 2012, Romanescu G., Stoleriu C., 2013). An anthropogenic factor with a special influence on the erosion of riverbeds is represented by the extraction of ballast in the area of construction of riverbeds.

The aim of the paper is to present the result of studies and research on how to determine the depths of hydrodynamic erosion in the riverbed in the areas of construction that are influenced by the morphological transformation of the riverbed. 


\section{Materials and Methods}

Studies and research were conducted on a lower sector of the Moldova River. The detailed research of the erosion phenomenon was carried out in the area of Soci locality, Iaşi County (Figure 1).

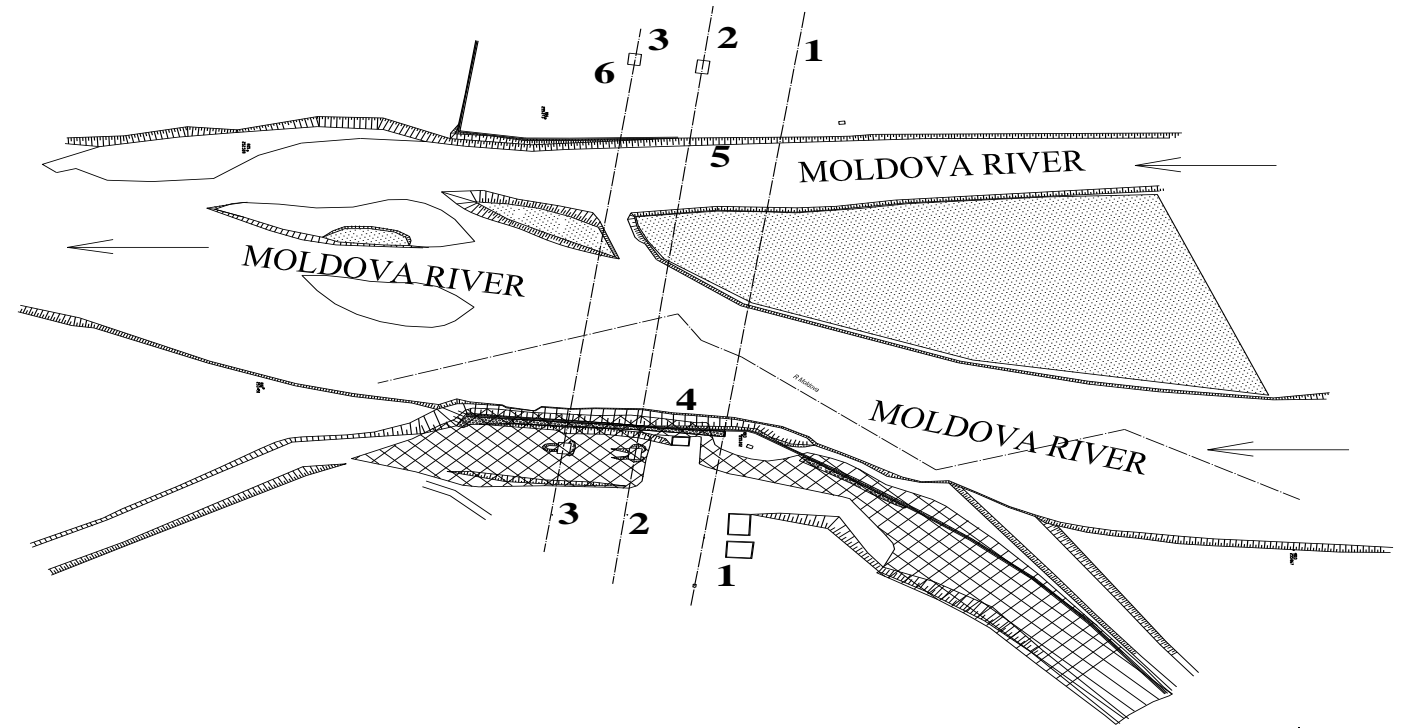

(a)

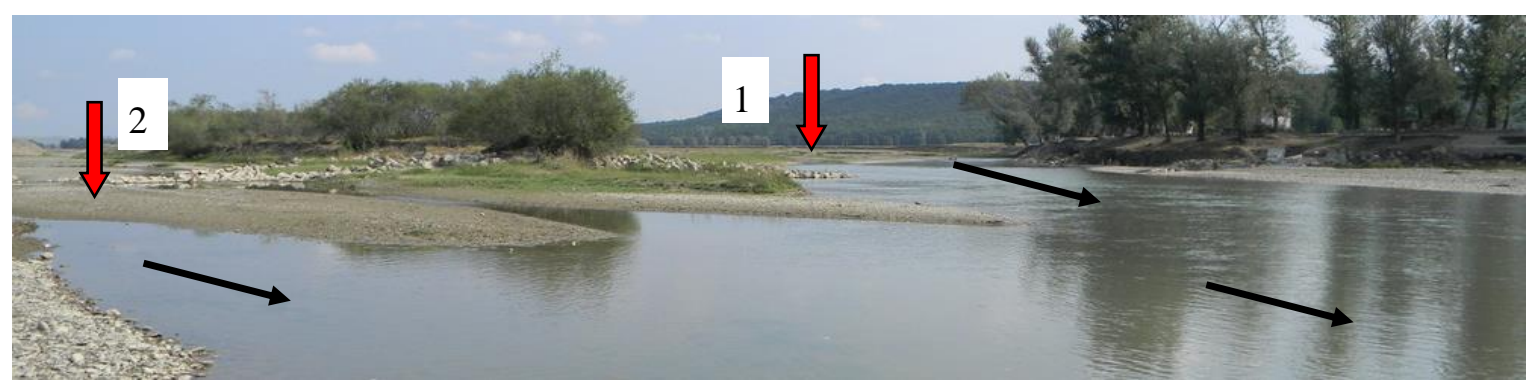

(b)

Figure 1. The location of adduction pipes I and II in the undercrossing of the Moldova River: (a) topographic plan of the undercrossing (year 2006); 1 (AdI), 2 (AdIIa) and 3 (AdIIb) - adduction pipes; 4, 5 - protection works on the left and right bank; 6 - valve houses; (b) view of the Moldova river in the undercrossing area, 1, 2 - the main and secondary riverbed (Luca, 2012).

The Moldova River has a length of $160 \mathrm{~km}$ and a surface of the river basin 3,567 $\mathrm{km}^{2}$. The slope of the riverbed on the research sector was $1.30 \%$. The geographical coordinates of the analyzed sector are: latitude $47010^{\prime} 50.00^{\prime \prime} \mathrm{N}$, longitude $26037^{\prime} 10.11^{\prime \prime} \mathrm{E}$. The river sector in the research area has an NW - SE orientation. The Moldova River has a winding route in the study area, with multiple morphological changes of the minor riverbed. The undercrossing Timişeşti - Iaşi supply pipeline construction is located in the research area. The river presents on this section a regular route, approximately rectilinear, made by regularization works. 
The Moldova River presents in the research area two arms with different lengths $(380-400 \mathrm{~m})$. The left arm is more developed than the right arm. The undercrossing area of the supply pipes is arranged with shore protection works. The width of the minor riverbed varies from $260 \mathrm{~m}$ upstream, to $127.0 \mathrm{~m}$ on the main riverbed (left arm), respectively $74.0 \mathrm{~m}$ on the secondary riverbed (right arm) and $141.0 \mathrm{~m}$ downstream of the island (Figure 1.b). The maximum water depth varies from $4.74 \mathrm{~m}$ to $4.32 \mathrm{~m}$ along the studied river section.

The Moldova riverbed in the study area is made of a ballast layer with a thickness of $15 \ldots 20 \mathrm{~m}$. The ballast layer extends into the major riverbed over distances of $200 \ldots$ $300 \mathrm{~m}$. Upstream and downstream of the research area there are a number of active gravel pits.

The research material was composed of hydrological, hydraulic, topographic, geotechnical studies, safety in operation of hydrotechnical and environmental constructions, etc. The detailed researches were carried out in the period $2004-2018$.

\section{Results and Discussion}

The research of the erosion phenomenon at the watercourses allows to obtain the design data of the constructions located transversely or longitudinally in the riverbed. The design of bridges or the construction of rivers with pipelines involves a detailed knowledge of the depths of erosion. The design data are obtained directly by applying the relations from the norms and design standards on the interested field (PD 95-2002). For important objectives, design data can be obtained indirectly from the research of the erosion phenomenon in the laboratory or in the field.

Such a situation was imposed by the fast-paced hydrodynamic erosion produced in the Moldova riverbed in the section of Soci locality from Iași County. On the river sector are located in the underpass at a distance of $25 \mathrm{~m}$ three the three pipes of the drinking water supply Timișești - Iași. The first pipe (ADI, the first upstream) is made of cast iron and has a diameter of $800 \mathrm{~mm}$. The pipeline was put into operation in 1911, and the section mounted in the riverbed was not rehabilitated until 2015. The other two pipelines (AdIIa, AdIIb mounted downstream of the first) are made of steel with $D=$ $1.00 \mathrm{~m}$. The two pipelines were put into operation in 1973, and the sections installed in the riverbed were not rehabilitated until 2015. The riverbed of the Moldova River on the section of the pipeline is calibrated and provided with shore protection works made of concrete slabs (Luca, 2012).

A technical expertise performed in the area of the pipelines in the Moldova riverbed initiated a research on the morphological transformations produced in the last period of time. The research took place between 2004 and 2015. The analysis models used to investigate the phenomenon of hydrodynamic erosion were the following:

A - The model imposed by the regulations for calculating the erosion depths in riverbeds for various constructions located in the riverbed.

B - Topographic model based on periodic measurements of the riverbed geometry in plan and in transverse and longitudinal profiles.

C - Model for simulating the erosion phenomenon on a river section by using computer programs in various languages. 
D - Satellite model for investigating morphological changes on a river section.

E - Hydraulic and aerodynamic simulation model in the laboratory of morphological changes on a river section.

The natural factors considered in the research were the morphometric characteristics of the riverbed, the flow and speed of water, the geotechnical characteristics of the riverbed, etc. The anthropic factors considered in the research were the exploitation of the ballast in the research area and the absence of the maintenance works of the riverbed and the construction of the underpass.

The hydrological studies elaborated in the research section on the Moldova river in the area of Soci locality indicated the following data (Luca, 2012):

- the average multiannual flow for the period 1959 - 2016 has the value of 31.806 $\mathrm{m}^{3} / \mathrm{s}$; during $1990-2016$ the value of $29.298 \mathrm{~m}^{3} / \mathrm{s}$ resulted;

- the maximum annual flows have a higher frequency in the last 25 years, being recorded even two floods per year (2010);

- the maximum flow was registered in 1991 at the Tupilaţi hydrometric station with the value of $1402 \mathrm{~m}^{3} / \mathrm{s}$ :

- during the research period (2004 - 2014) there were maximum flows with values of $1154 \mathrm{~m}^{3} / \mathrm{s}$ in 2005, $965 \mathrm{~m}^{3} / \mathrm{s}$ in autumn 2010 (in summer it was a flood with $660 \mathrm{~m}^{3} / \mathrm{s}$ ) and $510 \mathrm{~m}^{3} / \mathrm{s}$ in 2006 (Table 1 and Figure 2).

Table 1 Calculus discharges and levels in research area

\begin{tabular}{|c|c|c|c|c|c|}
\hline Probability, p \% & $1 \%$ & $2 \%$ & $5 \%$ & $10 \%$ & $50 \%$ \\
\hline $\mathbf{Q}_{\mathrm{p} \%}\left(\mathrm{~m}^{3} / \mathrm{s}\right)$ & 1810 & 1555 & 1200 & 940 & 28.8 \\
\hline $\mathbf{H}(\mathrm{m})$ & 257.15 & 256.95 & 256.50 & 255.90 & 253.10 \\
\hline
\end{tabular}

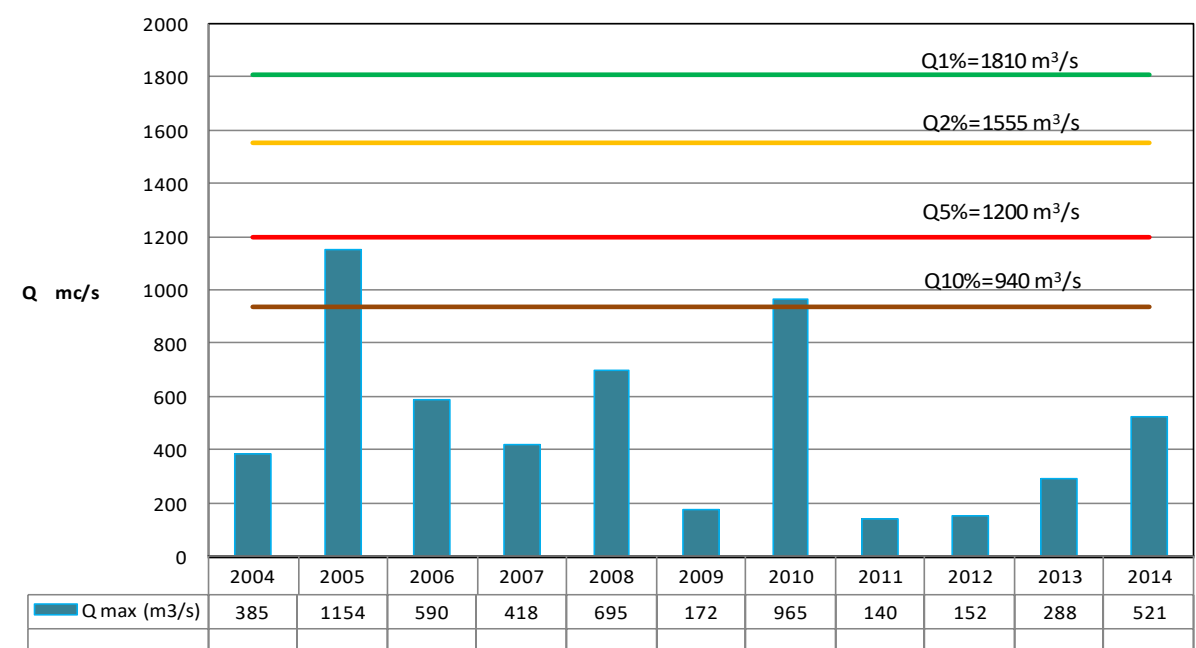

Figure 2. The frequency of annual maximum flows $(2004-2014)$ in the Soci section, Moldova River (Luca M., 2012)

The flow regime in the river basin of the Moldova River presents particularly large variations in time and space, having an obvious torrential character. The high degree of torrentiality is highlighted by the extreme multiannual values of runoff. In the research area there are high values of the torrential coefficient in the case of average 
monthly flows (about $170 \ldots$ 175) and even annual ones (about 5-6). The solid flows are in a direct ratio proportional to the liquid flows, the increase of the latter involving the increase of the quantities of alluvium transported in suspension and by crawling (Luca M., 2012).

The research carried out for model A (imposed by the calculation regulations for the constructions located in the riverbeds) for the determination of the erosion depths in the location of the three supply pipes various constructions located in the riverbed. In the literature are not presented relationships that determine the depths of erosion in the bed of a river over time The exact way to assess erosion over time is done by direct measurements. But, the process has the disadvantage that it presents what was and not what will be.

For the research sector, in which the riverbed has two arms separated by an island, two analysis and calculation variants were analyzed:

a - the variant in which the two arms of the river and the island simulate the presence of a bridge; the depth is determined by the relationships used for the erosion produced by the piles of a bridge (Mitoiu and Marin, 1999):

$$
E=\frac{v_{m p}}{v_{m l}} \quad(1), \quad a f_{g}^{\max }=h_{a f \max }-h_{\max }
$$

where $\mathrm{E}$ is the general leakage coefficient; $\mathrm{V}_{\mathrm{mp}}$ - average water speed before pouring; $\mathrm{V}_{\mathrm{ml}}$ - particle entrainment speed;

$\mathrm{b}$ - the calculation relationship used for the erosion produced downstream by a river overflow; the hypothesis adopted takes into account the fact that the riverbed consists of weakly cohesive ballast deposits, a situation that causes large erosion depths; the calculation relation has the form (Mitoiu and Marin, 1999):

$$
h_{e r}=2,4 \cdot q \cdot\left(\frac{\eta}{w}-\frac{2,5}{v_{a v}}\right) \cdot \frac{\sin \alpha_{a v}}{1-0,175 \cdot \operatorname{ctg} \alpha_{a v}}+0,25 h_{a v}
$$

where $q$ is the specific flow; $v_{a v}$ - the speed of water downstream; $\eta=1.5 . .2-$ coefficient depending on the non-uniformity of the velocity distribution; $w$ - falling speed; $d$ - diameter $d_{90}$ of the material of which the riverbed is made; $\gamma_{s}$ - the specific weight of the granules in the bed of the riverbed.

Geometric calculation parameters were taken from the cross-sectional and longitudinal sections obtained by topographic measurements (geodetic slope - $i$, elevations, surfaces, lengths). In order to apply the two calculation relations, limnimetric keys were drawn up on the two arms of the river, as well as on the total riverbed downstream of the island; thus the flow rates and the water level in the calculation sections were obtained. The hydraulic data were obtained with the calculation relations of the permanent movement in the riverbeds applied to the existing conditions in the site (water velocities, depths for calculation flows). The flow depths obtained with the two relations are differentiated for the same flow and parameters of the calculation section. The results obtained in the research area presented values from $0.75 \mathrm{~m}$ to $3.65 \mathrm{~m}$ in longitudinal profile in for flows with the calculation probability $p=20-0.1 \%$. The research results were capitalized on the design of the rehabilitation works of the constructions present in the riverbed.

The topographic model $(B)$ based on periodic measurements of the geometry of the riverbed in plan and in transversal and longitudinal profiles was made starting from 2004 
and completed in 2015. In 2015, rehabilitation works were carried out on the subversion construction of the Timișești - Iași supply pipelines, a situation that influenced the morphology of the riverbed. The obtained results were materialized by the evolution of the erosion depths on the considered river sector over an interval of about $5-15$ years.

The experimental research in the field presented the following stages:

- elaboration of the basic topographic plan of the researched river sector; the basic plan was made in 2005; the topographic plan was completely redone in 2012, 2015 and completely completed on the left bank in 2008 (Figure 3.b);

- topographic measurements for the realization of the basic transversal profiles through the riverbed in characteristic research sections in 2005; completing the transversal profiles at time intervals, or when changing the riverbed configuration due to floods (Figure 3.a); on the research section, 15 total transversal profiles and 7 - 9 completion profiles were made on each bank;

- topographic measurements for the realization of the longitudinal profile through the riverbed and its updating at time intervals, or at the modification of the riverbed configuration following the floods.

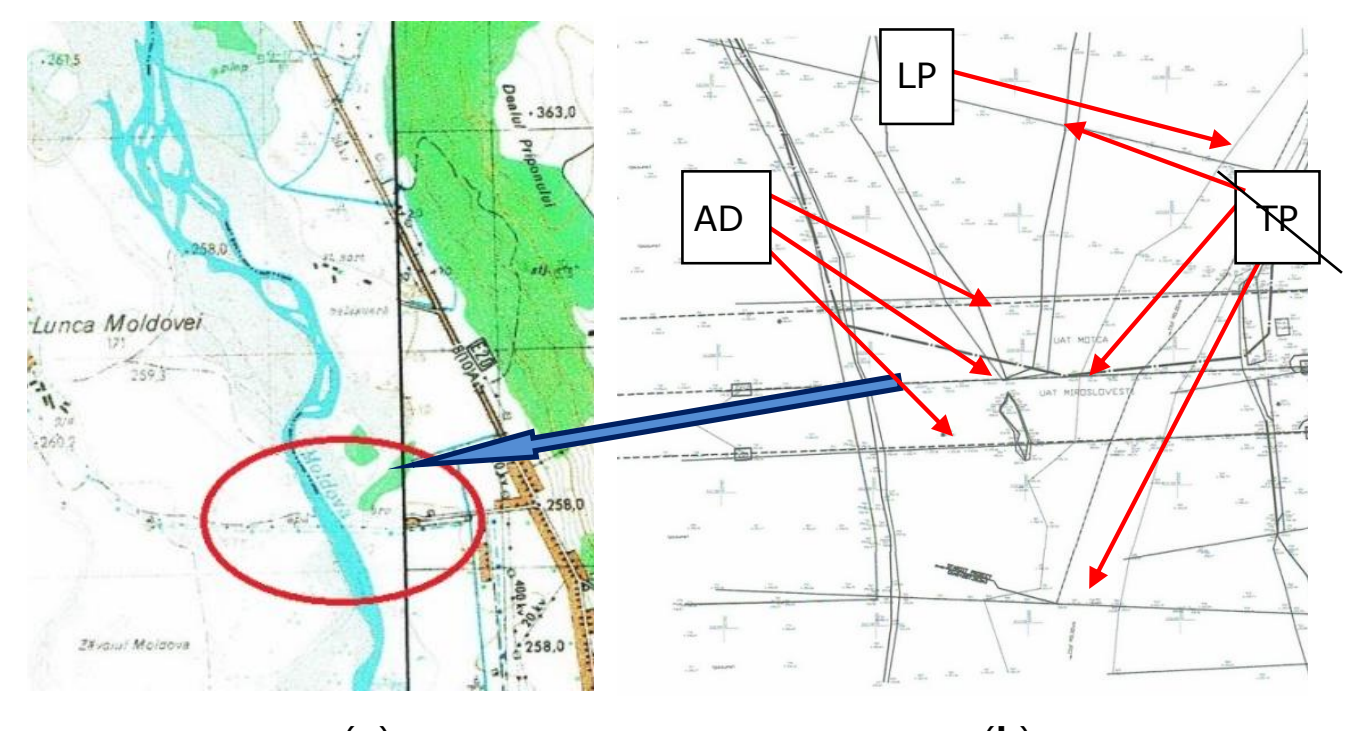

(a)

(b)

Figure 3. Situation plan of the research area on the Moldova River: (a) location of the study area; (b) location of transversal (TP), longitudinal (LP) and supply pipes (AD) profiles on the research sector.

A main component of the field research consists of taking photographic and video images in the analysis sections of the morphological changes of the riverbed. The research carried out in 2004 and 2005 showed an alluvial clogging of the shore protection works on lengths of $3-12 \mathrm{~m}$ from the riverbed (Figure 4 ). The value of the hydrodynamic erosion of the riverbed was evaluated on the longitudinal and transversal profiles (Figure 5, Figure 6 and Table 2). The measured values were compared with those calculated according to the standardized calculation relationships or considered significant in the research. 


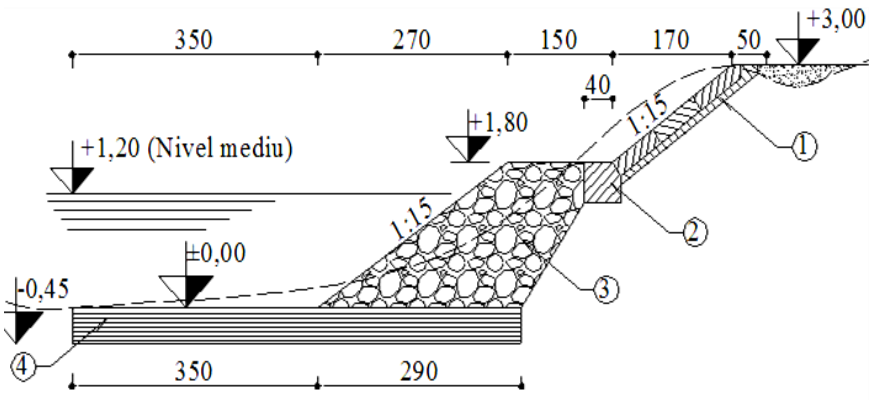

(a)

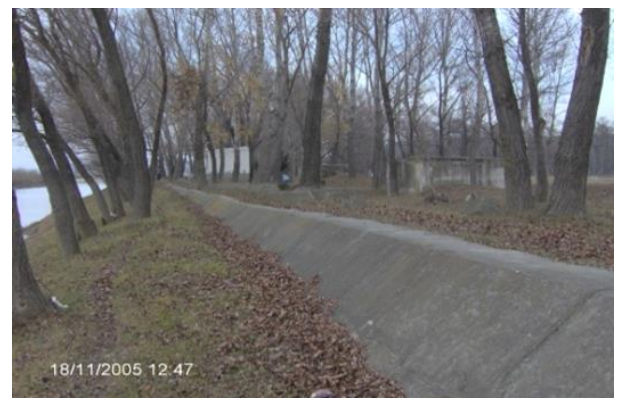

(b)

Figure 4. The degree of clogging of the shore defence works on the Moldova river in the research area, year 2005: (a) type of shore protection in the area of the pipes; (b) the degree of clogging of the left bank (Luca M., 2005).

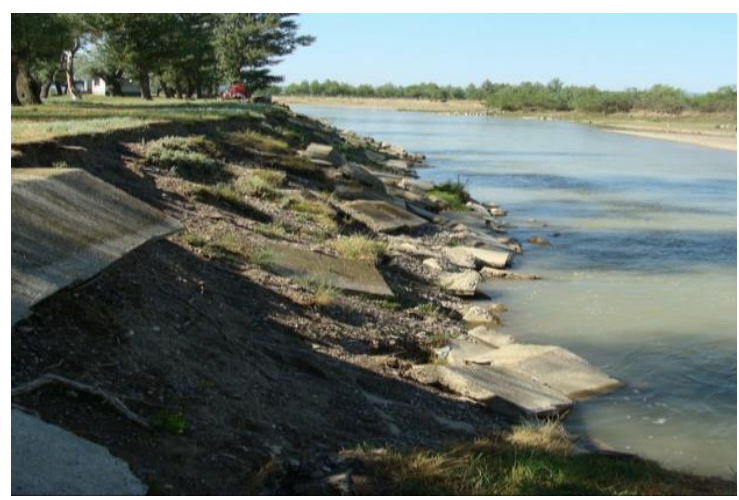

(a)

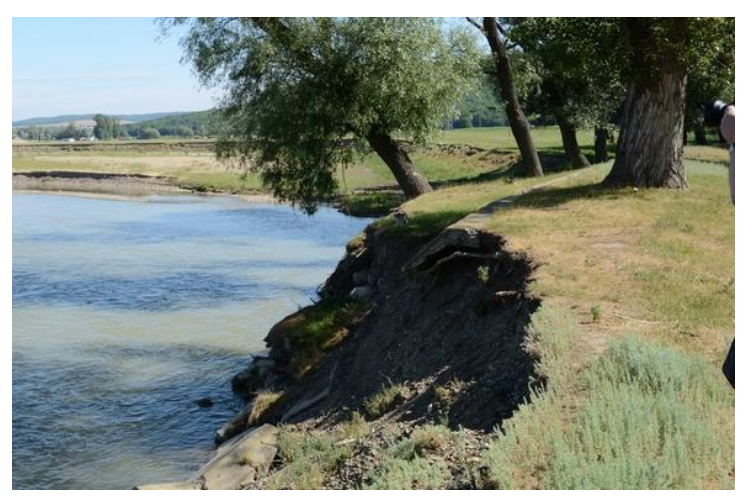

(b)

Figure 5. The state of the left bank of the Moldova River: (a) total degraded shore protection, year 2010; (b) the advance of the river on the shore after the destruction of the protection, year 2012 (Luca M., 2012).

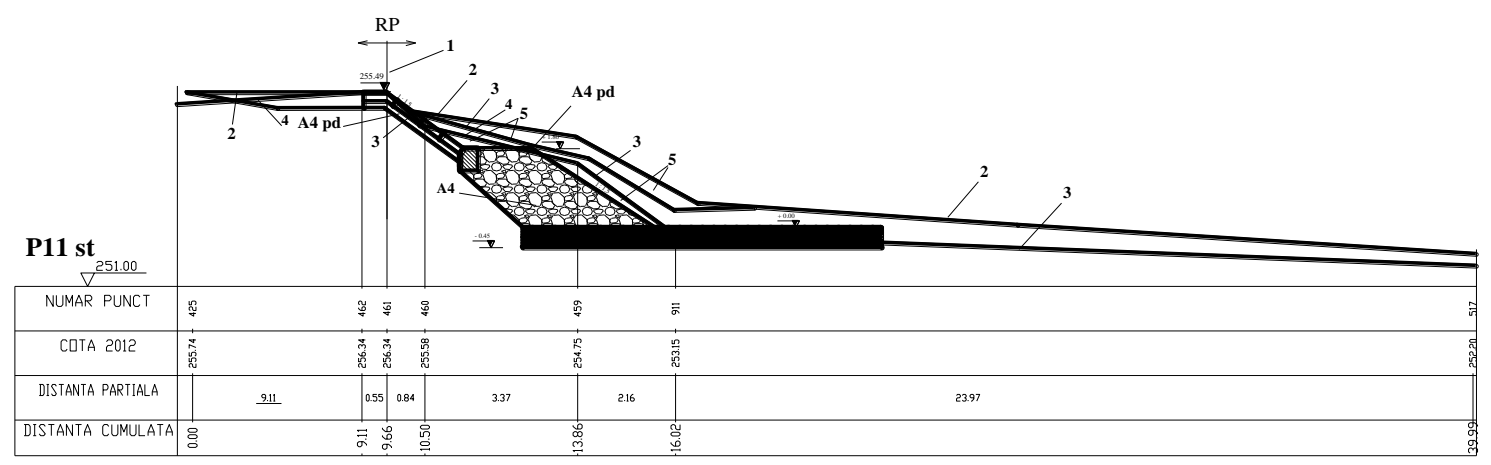

Figure 6. Time analysis of the erosion phenomenon of the left bank of the Moldova River, cross profile P11 left: 1 - reference point 2; 2 - shore line, year 2006; 3 - shore line, year 2008; 4 - shore line, year 2012; 5 - layer of alluviums; 6 - shore erosion area; A4 - type bank of defence; A4 pd - partially degraded shore defence.

The research of the erosion phenomenon by using the data from the longitudinal profiles allowed the analysis of the process of descending the bottom of the riverbed in time, a situation given by the action of natural and anthropogenic factors in the study area. 
Table 2. Shore erosion monitoring in the transversal profile Pt 10 Ift., Moldova River

\begin{tabular}{|l|c|c|c|c|c|c|c|}
\hline Data & 2004 & 2005 & 2006 & 2008 & 2010 & 2012 & \multicolumn{1}{c|}{2014} \\
\hline $\boldsymbol{L}(\mathrm{m})$ & 12.91 & 12.28 & 11.32 & 4.87 & 1.68 & -1.54 & -6.11 \\
\hline $\boldsymbol{H}_{\mathrm{er}}(\mathrm{m})$ & - & - & $0.62-0.84$ & $1.27-1.72$ & $2.14-2.61$ & $2.72-2.91$ & $3.04-3.61$ \\
\hline Obs & - & - & - & D.p.ap.m & D.p.ap.m & D.p.ap.m & Er.m. \\
\hline
\end{tabular}

The depth of erosion in cross sections and longitudinal plan profiles increased between 2004 and 2015, a situation that influenced the stability and structure of the shore defence. Also, the accentuated erosion of the Moldova riverbed has led to the partial and total degradation of the pipelines under the crossing. In 2015, the undercrossing construction was rehabilitated by installing new pipes at a greater depth depending on the outflow depths evaluated by the calculations presented previously.

\section{Conclusions}

The fast and repeated floods at short intervals, but also the exploitation of the ballast at the limit of the research area most favoured the development of the hydrodynamic erosion phenomenon.

The research of the erosion phenomenon at river basins by using topographic measurements at time intervals highlighted the mechanism of degradation of shore defence works under the action of natural and anthropogenic factors.

The erosion depths calculated with the relations from the design norms are for certain cases and cannot be capitalized in other situations given by the presence of constructions and installations in the riverbed (the case of undercrossing pipes). The regulations need to be reviewed and supplemented with the latest research results.

The research of the erosion phenomenon on the whole perimeter of the riverbed, by using hydraulic-mathematical models, is an efficient solution for the design of constructions and installations located on the entire width of the riverbed.

\section{References}

1. Luca, M., (2006) Expertiză tehnică privind starea de siguranţă în exploatare a subtraversării râului Moldova - zona Soci, jud. Iaşi a conductelor din captarea Timişeşti. SC Polias-Instal SRL Iași.

2. Luca, M., (2012), Expertiză tehnică privind lucrări de reabilitare în zona de subtraversare râu Moldova a conductelor de aducţiune apă Timişeşti, sat Soci, jud. Iaşi. SC Polias-Instal Iaşi.

3. Luca M., Tamaşanu F., Luca Al., L., Ilie G., (2016) Research on the stability of the defence works to eroded river beds. Ovidius University Annals, Series: Civil Engineering, Issue18, Ovidius University Press, p. 33-41.

4. Mitoiu C., Marin G. (1999), Regularizarea albiilor de râuri, Ed. BREN Bucuresti.

5. Romanescu G., Stoleriu C. (2013). Causes and Effects of the Catastrophic Flooding on the Siret River (Romania) in July-August 2008. Natural Hazards, 69:1351-1367.

6. Author 1, A.; Author 2, B. (year) Title of the chapter. In Book Title, 2nd ed.; Editor 1, A., Editor 2, B., Eds.; Publisher: Publisher Location, Country, 2007; Volume 3, pp. 154-196. 